PART SEVEN

BIOGRAPHY 
M. Beck - 9789047422938

Downloaded from Brill.com๑4/26/2023 12:11: 07PM via free access 


\section{GHAPTER TWENTY-FOUR}

\section{XENOPHON}

\section{BEGK}

The Cyropaedia is a novelistic treatment of Cyrus the Great's life with the express didactic purpose of imparting to its readers an appreciation of the elements of effective leadership. ${ }^{1}$ A comprehension of Xenophon's purpose is essential to understanding his use of time, since many of the most didactic parts of the book are relatively long sections of dialogue interspersed with brief narrative passages. ${ }^{2}$ The question that the Cyropaedia poses is a simple one: what in Cyrus' birth (genea), natural ability (phusis), and education (paideia) enabled him to found and maintain such a large empire, uniting such a wide variety of peoples, over such an immense geographic extent? The fictionalized biographical form adopted by Xenophon presents the growth and maturation of Cyrus' leadership skills as the natural outcome of a longterm educational, interactive, and interpersonal developmental process. Xenophon's portrayal of Cyrus' development into a charismatic individual can only unfold over time and in contact with others.

There are four discernable 'phases of temporal movement' in the Cyropaedia, which present the story of Cyrus' life from birth (I.2.I) to death (8.7). ${ }^{3}$ The first period, which narrates the education and development of Cyrus, is coextensive with book I. The other three phases, which occupy books 2-8, expose the narratee to a mature Cyrus who effectively copes with all manner of situations as they arise. They correspond to Cyrus' conquest of Assyria (Babylon; 2.I.I-7.5.36), the

\footnotetext{
${ }^{1}$ I have consulted the OCT edited by E.G. Marchant (I9Io) and W. Gemoll's Teubner edition (I9I2). I cite the Greek text according to Walter Miller's, whose Loeb edition (I9I4) and translations I have also used. Philip Stadter's article (I99I) brilliantly addresses many of the issues dealt with in this chapter and was of inestimable value to me. The reader is urged to consult it for further enlightenment on many subjects I could only briefly refer to here.

${ }^{2}$ Cf. Gera 1993 on the use of dialogue in the Cyropaedia.

${ }^{3}$ On this and the following see Stadter 1991: $474-477$. For a sweeping inclusive definition of biography see Momigliano I993: II.
} 
first year of his reign as king of Babylon (7.5.37-8.6.19), and his death in old age (8.7). Our analysis of the narrator's use of time will proceed along these outlined phases.

\section{Phase I: Cyrus' education and development}

This temporal phase warrants a detailed analysis since it represents the most sophisticated part of the work vis-à-vis time. The prologue (I.I.I6) sets forth the topics of leadership and obedience oscillating from the human world in which men seek, for the most part unsuccessfully, to establish and maintain dominance over other men, to the analogous realm of mankind's successful domestication of animals, before returning to the human sphere with the success story of Cyrus. Temporally the narrator begins at an indefinite period in his own lifetime when he first reflected on the historical vicissitudes of various forms of government (democracy, monarchy, oligarchy) in response to popular upheavals. The sustained durative nature of the narrator's reflections and observations is underlined by the use of the imperfect tense (edokoumen, enenooumen, enethumoumetha, egignōskometha, etc.), while the omnitemporal or iterative character of recurring or habitual behaviors in the animal and human realms is presented generally with the present tense and the iterative subjunctive with the particle an. The realization (enenoesamen) that Cyrus proved capable of mastering this seemingly impossible task disrupts the narrator's pessimistic reverie and compels a change of opinion on his part. His knowledge (ismen) appears to approach certitude as he summarizes the widespread and unquestioned obedience Cyrus' rule occasioned among numerous subjugated peoples, in contrast with that of other kings who strive only to maintain power over their respective subjects. We are thus given a proleptic glimpse of Cyrus' eventual greatness in adulthood before the narrative begins with his childhood and youth. ${ }^{4} \mathrm{~A}$ man capable of such effective leadership over such far-flung territories warrants study, we are informed, and this narrative promises to present the results of the narrator's investigation into the natural endowments and educational background of Cyrus.

\footnotetext{
${ }^{4}$ This type of rhetorical magnification of the subject (auxesis, amplificatio) is typical in the prologues of ancient historical works. Cf. Marincola i997: 34-43.
} 
The narrative proper commences with the usual biographical topos of genos: Cyrus' parents are Cambyses and Mandane (I.2.I). The narrator elects not to present childhood anecdotes, including the prophecy, attempted exposure, discovery, and assumption of the throne, as reported by Herodotus (I.IO7-I30), which, though apocryphal, would conduce to his expressed aim of presenting Cyrus' phusis. Instead he describes Cyrus' advantages in typical Xenophontic style with a string of superlatives (eidos men kallistos, psukhēn de philanthrōpotatos kai philomathestatos kai philotimotatos) representing characteristics that render him personally appealing, intellectually superior, and capable of enduring toil and danger. The alleged sources of this information are stories and songs related even today, a reference to the narrator's own time. This cursory description of Cyrus' physical and intellectual endowments is abruptly followed by an omnitemporal discussion of Persian education (I.2.2-I6), reminiscent of Herodotus' (I.I3 $\left.{ }^{-}{ }^{-I} 40\right)$ and Plato's (Alc. I I20e-123e), which in turn sets up many of the themes developed in Cyrus' interaction with his grandfather Astyages. As we are informed later (I.3.I), this was 'the education that Cyrus received until he was twelve or a little older'. We are thus encouraged to read this omnitemporal account in retrospect as a narrative of Cyrus' own education. One section of this narrative (I.2.I5) briefly supplements information about the Persian constitution regarding access to education and offices that he refrained from mentioning earlier (internal completing analepsis). The final section of this omnitemporal narrative is then located in the narrator's own time as he discusses some of the residual signs (marturia) of this training evidenced in contemporary Persian customs regulating the public display of certain bodily functions (I.2.I6). ${ }^{5}$ The

5 The Cyropaedia contains frequent references to the narrator's own time that usually provide contemporary supporting evidence for time-honored customs. Cf. e.g. I.3.2 (Persian dress and frugal lifestyle); I.3.9 (procedures associated with the royal office of wine pourer); 4.2.8 (Hyrcanians even to this day hold positions of trust and authority); 4.3.2 (custom of conveying wives and concubines to the battlefield); 6.I.27 (Cyrus abolished the method of managing a chariot still employed today among the Cyrenaeans); 7.I.45 (descendants of Egyptians continue to dwell in the interior of Asia Minor to this day); 7.I.47 (the scythe-bearing chariots still in use today by successive Persian kings); 7.3.15 (the monument of the eunuchs who committed suicide over the bodies of Abradatas and Penthea is still standing); 7.5.70 (same type of guard instituted by Cyrus maintained over Babylon even today); 8.I.6 (as instituted under Cyrus, nobility still are in constant attendance at court); 8.I.7 and 24 (institutions inaugurated by Cyrus still maintained today); 8.3.9 (Persians stand where king will pass just as they do today); 8.3.13 (tradition of wearing a filet around the tiara retained even now); 8.3.34 (the procession of the king, as instituted by Cyrus, continues to be conducted in the present); 8.4.5 
narrative's return to Cyrus' deeds beginning with those of childhood (praxeis, arxamenoi apo paidos) is then signaled (I.2.16).

In the following section (I.3.I-4.3) the narrator elects to recount Cyrus' childhood from approximately his twelfth year and to reprise only some of the specifics of his training up to this age with completing internal analeptic references presented in part by Cyrus (actorial analepsis) discussing his own past educational experiences in Persia (I.3.I5-I7) and later by the primary narrator (I.4.3). An ellipsis of this magnitude in true ancient biography is quite common, owing often to the lack of information on the early childhood experiences of wellknown individuals. ${ }^{6}$ The presence of this ellipsis here in a largely fictional account indicates authorial intent, however. ${ }^{7}$ It is evident that this section will serve to highlight his natural charm and aptitude as well as the benefits he has derived from his Persian education and the Median training he now receives.

His encounter with his grandfather, the Median king Astyages, is presented in long scenic passages of direct speech that are interspersed with brief narrative ones. The purpose of this detailed encounter is to stress the difference between the Medes and Persians in regard to frugality and temperance of lifestyle (sōphrosune $\vec{e}$, a contrast that is explicitly made (I.3.2), including a reference (nun eti) to the narrator's own time period. We see through Cyrus' eyes the external trappings of Median royalty adorning his grandfather's person. The poverty of the Persians vis-à-vis the Medes is brought out indirectly inter alia by a reference to Cyrus' delight at having the chance to learn to ride horses, something that he cannot do among the Persians, where the horse is a rare animal because of the mountainous terrain (1.3.3). In a long exchange between himself and his grandfather Cyrus critiques luxurious Median dining and drinking practices (I.3.4-I I).

\footnotetext{
(custom of seating in accordance with honor introduced in time of Cyrus continues to present day); 8.5.28 (the wonderful beauty of Cyrus' wife, the daughter of Cyaxares, is still a topic today); 8.6.5 (the satrapies Cyrus established continue in the possession of the descendants of those who received them even to this day); 8.6.9 (Cyrus' organization of garrisons upon the citadels persists in present day); 8.6.16 (yearly visitation of the provinces still done); 8.8.I-27 (long postscript on the present degenerate state of the Persians). Cf. Stadter 1991: 472 n. i9 and $S A G \mathcal{N}$ г:392-394.

${ }^{6}$ Cf. Pelling I988 = 2002a: $283-300$ and I990a $=2002 \mathrm{a}: 30 \mathrm{I}-338$.

${ }^{7}$ Xenophon does not choose to exploit the story of Cyrus' childhood and his violent seizure of power as portrayed in Herodotus' Histories (I.IO7-I30) since in his fictional portrait Cyrus does no wrong to friends and family nor is he wronged by them.
} 
The interweaving or blending of the iterative and singulative modes is very interesting in these passages, rendering it difficult to gauge the amount of time elapsed. The primary narrator abruptly blends a series of iterative references in the encounter scene with Astyages with the singulative mode. After Cyrus kisses him in greeting, the primary narrator recounts his habitual treatment of Cyrus, employing imperfect tenses (I.3.3). This is continued to the next episode, which initially describes Astyages repeatedly entertaining his grandson with lavish dinners before proceeding to the account of one of their exchanges at a dinner (I.3.4). The dialogue allows the primary narrator the opportunity of giving a dramatic condensed version of Cyrus' impressions. Previous dining experiences, including his encounters with Sakas, are alluded to in actorial completing analepses (I.3.IO-II). There is one proleptic threat, wherein Cyrus promises to displace Sakas as his grandfather's cup bearer (I.3.9). This threat is later never realized, however, as Cyrus wins over Sakas too with his charm (I.4.5). That this vignette showcases in an exemplary way Cyrus' charming personality is attested in the summarizing iterative statement at the beginning of the section:

Such amusement he furnished them at dinner; and during the day, if he saw that his grandfather or his uncle needed anything, it was difficult for any one else to get ahead of him in supplying the need; for Cyrus was most happy to do them any service that he could.

(I.3.12)

As the time for Mandane's departure approaches, Astyages attempts to persuade Cyrus to stay with him by outlining future benefits and activities he would enjoy if he should stay with him (actorial prolepsis). The issue of the completeness of his training in justice (dikaiosune $\overrightarrow{\text { ) }}$, a concern voiced by his mother Mandane, is dealt with by Cyrus in an actorial completing internal analeptic anecdote recounting an episode in his Persian education (I.3.I6-I7). The beginning of the next chapter indicates that this dialogue with his mother was just part of their total exchange on the subject of Cyrus staying with his grandfather Astyages (I.4.I). ${ }^{8}$ Throughout Cyrus' encounters with his grandfather and mother the narratee is exposed to a 'sustained test of wills' as the young Cyrus repeatedly resists them and yet in the end obtains his desires, while retaining their love and affection. ${ }^{9}$

8 'In this way Cyrus often chattered on. At last, however, his mother went away, but Cyrus remained behind and grew up in Media.' Cyrus' talkativeness is alluded to later on in an actorial analepsis (I.4.12).

9 Tatum I989: 97. 
In a summarizing iterative section (I.4.I-6) many events are related encompassing Cyrus' personality transformation and gradual attainment of maturity in the context of his interpersonal relations with his peers, their fathers, and other older males, including the first tests of his abilities in horsemanship and hunting (I.4.4-5). The iterative mode is then given up for a singulative presentation of Cyrus' first real hunt in the wild (as opposed to the animals in the game park), in which he chases and brings down a deer, despite almost being thrown from his horse, and slay a boar (no definite temporal marker; I.4.7-8). This scene concludes with a brief dialogue between Cyaxares and Cyrus (I.4.9).

The narrative continues with several dialogue scenes between Cyrus, Astyages, and other boys, who encourage Cyrus to approach Astyages on their behalf, which he does (I.4.IO-I3). Cyrus, after an indefinite period of dejection, finally persuades Astyages to let him and the other boys hunt free roving game (I.4.I4-I5). The narrative of the hunt scene serves to reveal Cyrus' qualities in a competitive arena. This leads into an abrupt acceleration through several years of time ${ }^{10}$ and resumption of the narrative when Cyrus is fifteen or sixteen years old (I.4.I5-I6).

Cyrus' encounter with the son of the Assyrian king, his first military engagement, is the subject of this next section, narrated in the singulative mode (I.4.I6-24). In a dialogue between Astyages and Cyrus we glimpse the budding strategic ability of the future conqueror (I.4.I9). His tactical skills are as yet insufficiently developed: Cyrus is compared to a well-bred but untrained hound (kuōn gennaios apeiros) who rushes recklessly upon a boar (I.4.2I; cf. I.4.I5). Cyrus' intense passion for battle is clearly and grotesquely put on display as he rides around gloating over the slain (I.4.24). Cyrus then departs from Media and returns to Persia (I.4.25). A concluding scenic dialogue between Cyrus and an unknown Mede struck by his beauty serves to demonstrate his sōphrosune (I.4.26-27).

Cyrus, now back in Persia (no details of his journey are mentioned), ${ }^{11}$ resumes his education, beginning with one more year in the class of boys (I.5.I). This as well as his entry into the class of youths (ephēbes) is very briefly recounted in accelerated narrative tempo.

10 This is expressed in a brief iterative summarizing statement: 'Thus Cyrus passed most of his time, contriving some pleasure and good for all, but responsible for nothing unpleasant to any one'.

11 This represents a considerable ellipsis. 
The narrator then reports the ahistorical accession of Cyaxares to the throne upon Astyages' death, which leads into a discussion of the Assyrian king's intentions to obtain power over the Medes and Cyaxares' response to this threat (I.5.2-6). Cyaxares, who gets wind of this plot, enlists the support of the Persians and in particular the leadership skills of Cyrus, who has now (another considerable ellipsis), as we are informed, 'completed his ten years among the youths (ephēbes) also and was now in the class of mature men' (1.5.4). Cyrus accepts the invitation and appears before his army to address them in a speech to his troops in which he stresses inter alia the preparatory value of education (including knowledge of the gods) for the upcoming confrontation (I.5.7-I4). After a brief transition Cyrus enters into a long conversation with his father that presents the secrets of good generalship (I.6.I-46). Perhaps the most important didactic section of the work, this dialogue contains numerous internal actorial completing analeptic references to Cyrus' prior training in the form of reminiscences (I.6.3, $5^{-8}$, I2- ${ }^{-} 5,20$, $23,28-29$ ) and an external actorial analepsis referring to an obsolete form of training administered in the time of Cyrus' forefathers (I.6.3 ${ }^{\mathrm{I}}-$ 32). ${ }^{12}$ Both Cyrus and his father function as secondary narrators in this dialogue when recounting these past events. Some of the analeptic references reflect that the same statements were made on more than one occasion in the past, that is, the iterative mode is indicated (oida se legonta aei, r.6.6). Cyrus predictably puts into action much of his father's advice in the subsequent books.

\section{Phase II: Cyrus the conqueror}

In this long section of the work, representing the second temporal phase of Cyrus' life, the narrator artfully intermingles scenic passages with singulative and iterative narrative passages (2.I.I-7.5.36). A reading of the first few sections of book 2 nicely illustrates this technique. After a brief transitional paragraph describing Cyrus' crossing of the Persian frontier and his entry into Media, the narrator again resorts to scenic presentation of a dialogue to present the fundamentals of the military situation, with the interlocutors now being Cyrus and Cyaxares (2.I.I9). Another brief narrative transition introduces speeches Cyrus deliv-

${ }^{12}$ Cf. also I.6.45-46, which is a general external analepsis presenting the 'lessons of history'. 
ers successively to the Persian peers (hoi homotimoi) and to the soldiers with some audience response (2.I.II-I8). The following section of the work outlines the measures adopted by Cyrus to reorganize, equip, and train his army for battle prior to the arrival of the enemy, without the passage of time being clearly chronicled (2.I.20-3I). The iterative mode abounds as his continuous efforts are narrated in detail. The narrator again makes brief reference initially, in the iterative mode, to Cyrus' habitual practice of providing entertaining conversation at dinner (2.2.I), prior to presenting, in the singulative mode, an illustrative example of this practice (2.2.I-3I). Occasionally past events are referred to analeptically, as when, for example, Hystaspas, as a secondary narrator, recounts, in his conversation with Cyrus, what happened at dinner the day before yesterday (2.2.2-5; actorial completing analepsis). The summarizing iterative statement which concludes this dinner conversation reveals its incompleteness: 'Things of this sort, both grave (spoudaia) and gay (geloia), were said and done at the dinner party' (2.3.I).

Many of the somewhat longer narrative passages present details of military affairs (e.g. battle with Assyrians, 3.3.57-4.I.I). ${ }^{13}$ Unlike Xenophon's $(\rightarrow)$ Anabasis or Hellenica, which orient the narratee with frequent geographical and temporal references, the narrator in the Cyropaedia eschews precise temporal references and holds geographic references to a minimum. The sporadic and vague nature of the temporal references thus conveys the passage of time but does not permit an exact tally of days or years. ${ }^{14}$ The impression thus conveyed to the narratees is one of

13 Cf. also 6.2.4-I3 (preparations for battle with Croesus); 6.3.I-9 (final day's march prior to engaging with Croesus' forces); 7.I.I-6 (description of pre-battle activities and equipment); 7.I.23-28 and 30-4I (narrative of battle with Croesus' forces); 7.4.13-5.6 (Cyrus departs from Sardis and marches to Babylon, subduing territories on the way, and, upon his arrival, arrays his forces before Babylon); 7.5.I0-I9 (siege operations before Babylon); 7.5.26-36 (capture of Babylon).

14 For example, 2.3.I ('on the next day'); 3.3.I ('on the following day'); 3.3 .5 ('that night $\ldots$ on the next day'); $3 \cdot 3.29$ ('on the following day'); 3.3 .34 ('early on the following day'); 4.2.28 ('when daylight came'); 4.2.29 ('as it was summer'); 4.4.I ('when it was just past midday'); 4.4 .9 ('when it was day'); 4.5.I4 ('at daybreak'); 5.2.I ('early the next morning'); 5.2 .2 ('toward evening of the second day'); 5.2 .22 ('when day dawned'); 5.3.I ('they arrived on the fourth day'); $5 \cdot 3.28$ (six or seven days predicted by Gadatas for march); $5.3 .5^{2}$ ('at midnight the signal horn sounded'); 5.3 .57 ('they proceeded all night long'); 5.5 .5 ('on the following day'); 6.I.I ('after spending that day in the manner described'); 6.2.25 ('more than fifteen days' journey'); 6.3.I ('on the first day'); 6.4.I ('early on the following day'); 6.I.I4 ('for winter is coming, you know') 7.2.2 ('when daylight came'); 7.3.I ('on the following day'); 7.4.4 ('that night ... at daybreak'); 7.5.33 ('when day dawned'). Cf. Stadter I991: 475. 
a series of episodes with intervening indefinite segments of time being either completely suppressed (ellipsis) or vaguely hinted at (summary). This episodic style with frequent use of ellipsis allows the narrator to maintain his focus on Cyrus unimpeded by other extraneous and distracting circumstances. The use of dialogue adds considerable dramatic quality to the work, as frequent scenic passages present Cyrus and others interacting with various individuals and groups. ${ }^{15}$

In general a chronological progression from one scene to another is consistently maintained. There are some notable deviations from this pattern, however. Gobyras, as a secondary narrator, for example, directs the attention of the narratees to past events as he recounts analeptically $^{16}$ the murder of his only son at the hands of the Assyrian prince who has now assumed the throne at his father's demise (4.6.27). ${ }^{17}$ Croesus' account (as secondary narrator) of his past misfortunes represents a similar analepsis (7.2.17-24). This encounter with Croesus concludes with a proleptic iterative statement: 'At hearing these words Cyrus wondered at his good spirits, and after that he always used to take Croesus with him wherever he went ...' (7.2.29). In general, however, the use of the iterative mode is held to a minimum (e.g. 6.I.2324; 7.I.I, I.IO-I4, 4.I5). In the wake of the battle with Croesus, the narrator presents a brief analeptic analysis of the battle, in which he evaluates the merits of the enemy forces and Cyrus' army (7.I.46-49). Occasionally two events are presented as occurring simultaneously. For example, the presentation of the long parting scene between Abradatas and his wife Panthea, framed between references to Cyrus performing sacrifices and finding the omens from his sacrifice favorable prior to his final battle, has the effect of adding an almost holy quality to what the narratees are led to suspect will be the couple's final parting (6.4.I-I2). ${ }^{18}$

15 Bal [1985] I997: 60: 'The more dialogue a narrative text contains, the more dramatic that text is'.

16 This is an internal actorial completing analepsis, since Gobryas' daughter is portrayed as still in mourning for her dead brother $(5 \cdot 2.7)$.

17 On secondary narrators in the Cyropaedia see $S A G \mathcal{N}$ i:399-400.

18 The narratee's expectations are not disappointed (cf. 7.I.29-32 and 7.3.2-I6). The simultaneity of these two events is indicated by the way the narrator introduces the parting scene between Abradatas and Panthea, that is, with a reference to Cyrus performing the sacrifices as the rest of the army arms and arrays itself (6.4.I). This is just what Abradatas is doing in this scene, as his wife helps him don his armor (6.4.2-II). This is immediately followed by the narration of Cyrus finding favorable omens and commencing an address to his assembled generals, one of whom must be Abradatas (6.4.12). 
In another type of example of simultaneous activity in the military sphere, the narrator relates that Adusius is sent to Caria with an army while Cyrus stays in Sardis to make siege engines (7.4.I..$^{19}$

\section{Phase III: Cyrus king of Babylon}

In the wake of the war Cyrus' attention gravitates from the administration of Babylon to the administration of his newly conquered empire (7.5.37-8.6.19). Securing his personal safety and leisure and setting an example for others to follow appear to be his paramount concerns. Xenophon relies heavily in this section on the iterative mode to convey Cyrus' habitual behavior in the conduct of his empire $(7 \cdot 5 \cdot 37-40$, 68; 8.I.I6-2I, 23, 34, 37-44; 8.2.I-4, 25-28; 8.3.50; 8.4.2-5, 31; 8.5.3I6; 8.6.I6-I8, 22-23). Summary passages, both singulative and iterative, preponderate over 'scenes' (including direct speech) ${ }^{20}$ for the most part, as the narrator presents Cyrus' reflections, rationale, and behavior which led to the formation and observation of the institutions and customs that he describes (e.g. 7.5.58-7I; 8.I.6-8.2.I3; 8.6.7-IO, I4-23). ${ }^{21}$ The narrator exploits the iterative mode, in particular, as an especially effective means of summarizing long-term patterns of behavior or habitual activities. Prolepsis and analepsis are rare. ${ }^{22}$ We are thus swept through one year of the king's life in a few pages. ${ }^{23}$

\section{Phase IV: The death of Cyrus}

The next temporal phase covers Cyrus' (ahistorical) death of old age in Persia (8.7.I-28). What would be an ellipsis of enormous magnitude is narrowly avoided by an intervening summarizing section of extremely

19 Cf. also 4.2.I (which describes the arrival of messengers of the Hyrcanians while Cyrus is engaged in managing affairs); 5.3.25 (many Assyrians surrender their horses and arms while Cyrus is occupied with arrangements about a fortress).

20 For example, the speeches delivered by Cyrus, Artabazus, and Chrysantas $\left(7 \cdot 5 \cdot 4^{2-}\right.$ $\left.5^{6}\right)$ and by Cyrus and Chrysantas (7.5.72-8.I.5), by Cyrus (8.4.32-36; 8.6.3-6, I I-I3), by Cambyses $(8.5 \cdot 22-26)$, dialogues $(8.3 .26-47,4 \cdot 7-27)$.

21 Cf. however Cyrus' (7.5.72-86) and Chrysantas' (8.I.I-5) speeches.

${ }^{22}$ Cf. e.g. the internal prolepses at 8.5.2 (narratorial) and 8.6.I5 (actorial).

23 The length of the elapsed time period is indicated at 8.6.19 ('when the year had gone around'). Explicit indications of the passage of time are rare (e.g. 8.4.28: 'on the following day'). 
accelerated narrative which presents a brief epitome of the remarkable achievements of Cyrus' military activity immediately prior to this final phase (8.6.20-2I). Most of the general administrative activities involving the king that took place in the intervening years have been alluded to in the previous section, as the institutions and ceremonies that he inaugurates withstand the test of time. This includes such habitual behaviors as his seasonal change of residence (8.6.2 I-22). The positive response of his subjects to his rule over time is also mentioned in a brief iterative section (8.6.23). No specific incidents however are related. Cyrus' imminent death is proleptically indicated to him in a vision: 'Make ready, Cyrus; for thou shalt soon depart to the gods' (8.7.2). His loss of appetite on three successive days signals to him that he must summon his friends and family $\left(8.7 \cdot 4^{-5}\right)$. The rest of the section contains his words of advice to them, in which, as might be expected, he recounts briefly salient events of his life and the disposition of his empire (8.7.6-28). At the close of this final speech he shakes hands with those present and dies.

The final hotly disputed section of the book contains a long and detailed analysis by the narrator of why the enduring legacy that Cyrus strove to fashion was rather quickly derailed by declining moral standards, greed, decline in physical fitness, abandonment of traditional behaviors and discipline, increasing effeminacy, and ineffective military practices $(8.8 . \mathrm{I}-27)$. If this concluding section is authentic, then Xenophon does not seem to want to detract from Cyrus' achievements; in fact he concedes that without the personality of a ruler like Cyrus such achievements are not possible (8.8.I).

\section{Conclusion}

In conclusion, the Cyropaedia relies on a predominantly dramatic presentation of Cyrus. Dialogues and speeches abound. The character and personality of Cyrus is conveyed to us in his interactions with the other main characters in the drama of his life. These same dialogues or conversations often serve analeptically to fill in past events that have been suppressed through ellipsis (e.g. Cyrus' conversation with his mother Mandane regarding his prior training in Persia) or even serve the dual purpose of analeptically reprising past training and proleptically foreshadowing future behavior (e.g. Cyrus' long dialogue with his father Cambyses on military tactics, etc.). 
Several major ellipses occur in the representation of Cyrus' youth (phase I) and are only partially filled in by later analepses. Long scenic passages interrupted by briefer narrative passages are the rule. The longest narrative passages in phase II are generally descriptions of training, troop dispositions and battles. An exact reconstruction of the chronology is rendered impossible because of vague or infrequent temporal references. Ellipses are usually not indicated as the narratee is transported rapidly from one scene to another in an 'unrelenting accumulation of long dialogues'. ${ }^{24}$

In phase III of the work the narrator details Cyrus' year in Babylon spent primarily consolidating his conquests with the establishment of administrative institutions. The use of speeches is more evenly balanced with more frequent use of the iterative narrative mode to convey habitual activities undertaken by Cyrus and his subjects. The narrative pace of this section is generally accelerated vis-à-vis the prior sections as the narrator condenses in one book the events of one year. The intervening time period from the end of his first year in Babylon to his old age (when his parents are long ago deceased) is sketched very briefly. The final retrospective assessment of Cyrus' life, achievements, and thought is fittingly delivered by Cyrus himself on his deathbed in the work's fourth and final temporal phase.

${ }^{24}$ Stadter I99I: 46 I. 